\title{
Determinants of Financial Independence in Developing Countries (A Case Study of Kenya)
}

\author{
Dennis Muturi Muthara ${ }^{1}$, Jane Ndirangu-Muiruri ${ }^{2}$, William Kazungu Kingi ${ }^{1}$ \\ ${ }^{1}$ School of Business of Technical, University of Mombasa, Mombasa, Kenya \\ ${ }^{2}$ School of Business of Karatina University, Karatina, Kenya
}

Email address:

muturimuthara@gmail.com (D. M. Muthara),wmuiruri@gmail.com (J. Ndirangu-Muiruri), wkingi@tum.ac.ke (W. K. Kazungu)

\section{To cite this article:}

Dennis Muturi Muthara, Jane Ndirangu-Muiruri, William Kazungu Kingi. Determinants of Financial Independence in Developing Countries (A Case Study of Kenya). International Journal of Economics, Finance and Management Sciences. Vol. 3, No. 3, 2015 , pp. 325-329.

doi: 10.11648/j.ijefm.20150303.30

\begin{abstract}
The main objective of this study was to examine the determinants of financial independence in developing countries, with focus on Kenya. Two theories were looked into, the Dependency Theory and the Classical Dependency Theory. The research was based on fourteen departments in the Kenyan government. The three variables examined in this study include corruption, financial planning and balance of payment. The researcher measured to what extent each of the three variables affected financial dependency of a country. Secondary data from Transparency International, IMF reports, World Bank reports, Government reports by the auditor general, Vision 2030 reports, Kenya Economic Reports and other reports and journals was used. This data was analyzed using SPSS. This research established that there is a relationship between financial independence and financial planning as well as balance of payment. There was a positive correlation between financial planning and financial dependence and balance of payment and financial dependence. The researcher recommended that the government adopts better financial planning strategies such as reduction of recurrent expenditure and tightening the noose on revenue collection methods used as well as to improve on the amount of exports by expanding the range of products produced by the by the country for export.
\end{abstract}

Keywords: Gross Domestic Product, Multilateral Debts, Bilateral Debts, Debt Structure

\section{Introduction}

In the $21^{\text {st }}$ century, financial dependence has become rampant in third world countries in Africa, Asia, Oceanic and Latin America. These countries are characterized by low economic development, high infant mortality rate, and poor utilization of natural resources, high poverty levels and huge dependence on industrialized nations. These countries are also characterized by unstable governments, high rate of population growth, high levels of illiteracy and epidemic. A small number of elite class controlling the resources whereas the other millions live in abject poverty (Jeffrey, 2002). The $21^{\text {st }}$ century saw the formulation of the Millennium Development Goals (MDGs). The aim was to fight poverty, accelerate human development, and facilitate the gradual but more effective integration of the developing nations, especially Africa, into the global economy (Jeffrey, 2002). Despite the initiatives and measures such as the establishment of the African Union and the adoption of New Partnership for
Africa's Development (NEPAD) as the strategic programme of the Union whose effective implementation is intended to bolster Africa's effort towards meeting the MDGs, (GOK, 2005), Africa still remains poor. In Kenya, as at 2003, 56 per cent of the population was still living below the poverty line with a projection that at the current trend, 65.9 per cent of the Kenyan population would be living below the poverty line by 2015 (GOK, 2005).

From August 4, 2000 to August 3, 2003, Kenya's approved amount for Special Drawing Rights (SDR) was $\$ 190$ million but they drew \$33.6 million. From 21 November, 2003 to 20 November 2007, the approved amount for SDR was $\$ 150$ million and Kenya drew it all. From January 312011 to December 16 2013, the approved amount for SDR was \$488.52 million and Kenya drew it all. Kenya's request for a loan payout of $\$ 143$ million from IMF to help it cope with severe drought in the Horn of Africa and high food and fuel prices was approved. The release was part of a total release to Kenya of \$312 Million under its three years extended credit facility arrangement with IMF. The IMF executive Board also 
raised Kenya's loan ceiling to around $\$ 760$ million (GOK, 2013).

The IMF approved a \$508.7 million loan to help Kenya's economic program and its reform agenda to aid in implementation of the new constitution (Rogelio, 2011). Kenya's public debt has risen up to $\$ 21.11$ billion indicating the likelihood that it would touch the $\$ 22.22$ billion mark before the end of the current financial year going by the treasury's borrowing plan which includes a \$1billion Eurobond (CIA, 2013).

Kenya's public debt accounts for more than $47 \%$ of the GDP and this should be reduced to manageable levels of less than $35 \%$ of the GDP. The most important aspect is for the country to utilize borrowed money in all sectors that will speed economic growth avoiding too much wastage of public funds on non-core investments that helped to stifle economic growth in Kenya (GOK, 2013).

In the 1960s, the Asian Tiger countries were at the same level of economic growth with Kenya. These countries emerged from depending on foreign aid to becoming donors and lenders. They are no longer classified as Less Developed Countries (LDCs) but have graduated to Most Developed Countries (MDCs) status. Kenya on the other hand is still classified as a developing country with a Gross Domestic Product (GDP) of 1016, as compared with Asian Tiger countries such as Hong Kong (37,777), South Korea $(24,329)$, Taiwan $(20,930)$ and Singapore $(54,776)$, (IMF, 2013). Many questions have been posed as to why Kenya's economic performance is slow as compared to that of the Asian Tiger countries. Kenya began fading when it failed in its ethical structures to fight corruption, as compared to strategies such as zero tolerance to corruption, good economic planning and conducive economic environment that characterizes the Asian Tiger countries (T.I, 2013).

Given the direct impact of financial dependence on economic development and the emphasis placed by the Kenyan government on achieving the MDGs, this study clearly represents an important piece of research. It is anticipated that, the work will play an important role in bridging the knowledge gap concerning the financial management practices of developing countries, which have made them depended on aid and those of emerging Asian economic powerhouses which, although at economic par with Kenya in the 1960s, today rank at economic par with developed countries. This research project intended to find out the influence of internal factors within a country that make it to keep depending on Developed Countries for aid, grants, donations and loans to fund its own projects. Focus was on the new school of thought that the problems facing developing countries should not be blamed on developed countries but on developing countries.

\section{Objective of the Study}

The main objective of the study is to determine the factors that influence financial independence in developing countries.

\section{Literature Review}

Dependency is defined as the exploitation of the economic development of a country in relation to external influences such as cultural, political and economic factors on national development policies. There are many theories that have been developed by scholars and economists to explain the large disparity between More Developed Countries and Less Developed Countries, which leads the latter to depend on the former. Dependency is deep-seated, with a historical background rooted in the internationalization of capitalism. It is an ongoing process, which not only reinforces but also intensifies the unequal patterns in the two sets of states.

\subsection{Dependency Theory}

Dependency theorists divide the international system into two sets of states. One set is for those dominant, center or metropolitan. The other set of states a known as dependent, periphery or satellite. The dominant states were developed economies that were industrialized and financially stable, in the organization of economic co-operation and development. The dependent states included states of Latin America, Asia and Africa with a low per capita GNP and usually rely on exporting one or a few commodities for their foreign exchange (Khapoya, 2008).

Traditional neo-classical approach asserted that LDCs were late in coming to solid economic practices. Poverty would reduce once they learned the techniques of the modern economies. In their definition of dependence, the theorist also assumed that there existed external forces that were of importance to the economic activities of dependent states. The external forces ranged from international commodity markets, foreign assistance, multinational corporations, communication and other forms of industrialization in MDCs in representing their economic interest abroad (Khapoya 2008).

LDCs produced primary commodities which they export to MDCs for manufacture. They are manufactured and then sent back for sale in LDCs but the value added does not match cost that Developed Counties sell the manufactured commodities to LDCs. This costs of buying manufactured goods exceeds the export price at which the LDCs sold primary products to MDCs. Therefore this leads to LDCs earning less for their exports and paying more for their imports (Khapoya, 2008).

The dependency theory proponents emphasized that the European expansion of the 15th century and is still being maintained by both the power of the dominant states and the power of the elites in the dependent states. This is brought about by the fact that the interest of these elites coincide with the interest of the dominant states. These elites have a sincere belief that if they follow the prescription of liberal economic doctrine, then will open up economic development in dependent countries (Khapoya, 2008).

Proposed solution would be for LCDS to substitute imports so that they would not have to spend their foreign exchange to purchase manufactured goods from developed countries. However some obstacles to these solutions arose. The first 
was that most LDCs lacked the political will to transform from being primary product producers. Another obstacle was that the internal markets of LDCs were not large enough to enjoy the large economies of scale enjoyed by Developed Countries which helped them keep their prices low. The third challenge was that LCDs lacked control of their primary products especially when finding a market for the products abroad (Khapoya, 2008).

\subsection{Classical Dependency Theories}

A new school of thought arose and was called the World Systems approach. They argued that poverty in LDCs was due to continued exploitation by developed countries, and that poverty was directly related to evolution of the international political economy into a rigid division of labour which disadvantaged LDCs and favoured developed countries (Adil, 2007).

A group known as the modernization school developed theories as a result of policies based on the modernization theories and concluded that imperialism actively contributed to underdevelopment of these countries. Those internal conditions of third world countries such as close relations and their impact upon the utilization of economic surplus and its distribution of power as a primary barrier to development. Propositions have been made that the governments of third world countries intervene by nationalization of industries, (Adil, 2007).

These classical dependency theorists described underdevelopment and dependency from the third World point of view. They identified factors that contribute to backward economies such as imposition of unequal exchange by other countries. These theorist proposed solution such as partial de-linking from the international system and social revolution (Adil, 2007).

\subsection{Corruption}

Corruption is the illegitimate use of power to benefit private interest. Corruption is also defined as an action to secretly provide a good or service to a third party so that he/she can influence certain actions which benefit the corrupt, a third party or both, in which the corrupt person has authority (Senior, 2006).

There are three scales of corruption. The first scale is petty corruption, which happens within established social network and governing norms. It includes use of personal connections to get favors and offering or receiving of improper gifts to get things done. Corruption is very rampant in LDCs, which are characterized by lowly paid public servants who view it as an extra source of income (Glossary, 2011). The second scale of corruption is known as grand corruption. This is corruption that occurs in the highest level of government for example, Government agencies, departments and ministries (Glossary, 2011).

The third scale of corruption is systemic corruption, which is also known as endemic corruption. It is brought about by the weakness of an organization or process. It is influenced by factors such as monopolistic powers, transparency, low pay and the culture of impunity, discretionary powers and conflicting incentives (Lorena and Raul, 2001). High levels of corruption in a country's government leads to loss of funds which had been budgeted for development purpose. This in turn leads to budget deficit which forces a country to depend on other countries for loans and donations. Kenya has lost billions of shillings through scrupulous deals such as the Goldenberg scandal, the Anglo-leasing scandal. This is through corrupt deals by high ranking government officers, diverting money meant for development to their own pockets and thus forcing the government to borrow funds to bridge the deficit (Kwabena, 2001).

\subsection{Financial Planning}

Craig and Dollar (2000) contended that foreign aid improves the income growth of the recipient country if a healthy policy environment exists in the country. Further studies lead to an emerging consensus that, at best, there appears to be a small positive, but insignificant, impact of aid on growth (Bourguignon and Sundberg, 2007).

Fujita, Fabrice, Joachim, and Guoyong (2009) state that economic development is derailed by lack of sound financial plan, lack of appropriate public investment, and poor management of public administration. Sound financial plan entails making plans for a balance between the private and public sector.

A budget is the most basic element of financial planning of a government. There are two main elements of a government budget. One is the revenues which are usually derived from taxation. The other element is government expenditure which is comprised on government consumption such as spending on recurrent goods and services, government investment expenditure comprised of expenditures such as research expenditure and infrastructure investment expenditure, transfer payments such as retirement benefits (John, 2008).

\subsection{Balance of Payment}

Balance of payment is the record of all economic transactions between residents of a county who include individuals firm and government bodies and the rest of the world in a particular period. It represents all visible and invisible transactions of a country during a given period. It is a representation of s country's total current demand and supply of the claims on foreign currencies claims on its currency (Mathur and Raman, 2012).

The transactions include payments for a country's exports and imports of goods, services, financial capital and financial transfers. In formulation of balance of payments, the domestic currency of a country is used. Sources of funds for a country such as exports, receipts of investments and loans are recorded as surplus or positive, whereas uses of funds such as imports or investment in foreign countries are recorded as negative or deficit (Sloman, 2004)

Imbalances may occur on individual elements of BOP such as central banks reserve account or the sum of the two. An 
imbalance in the sum of the capital and current account makes the surplus countries to accumulate wealth while deficit nations continue to be highly indebted. A balance of payment deficit occurs if the sources of funds such as export goods sold and bonds sold are less than the uses of funds such as paying for imported goods and foreign bonds purchased. The current account of a country shows the net incomes on export minus the net payments for the imports, the factor income from abroad and cash transfer (Antiam, 2009). The capital account records the net changes in ownership of foreign assets including the foreign exchange market operations of a nations central banks, the loans and investments between the county and the rest of the world (Crabbe, 1996).

\section{Methodology}

The researcher used secondary data collected from the government budgetary estimates reports from The National Treasury, government economic surveys, Vision 2030 Reports, Transparency International, IMF reports, World Bank reports, Government reports by the auditor general, Kenya Economic Reports and other financial and economic reports and journals. The Kenya National Treasury formerly known as the Ministry of Finance and the Ministry of Planning and Devolution are the two ministries that are relevant to this study. This is because these two ministries encompass the major departments such as the KRA, CBK, Revenue Allocation, Vision 2030, Budgetary Committees and other departments which have very crucial information regarding the study. These two ministries were selected by the researcher because they had all the information that was relevant to the study in regards to financial independence.

\section{Analysis}

The coefficients table offers the necessary information to predict financial independence.

Table 1. Correlation.

\begin{tabular}{llll}
\hline & $\begin{array}{l}\text { Financial } \\
\text { Independence }\end{array}$ & $\begin{array}{l}\text { Financial } \\
\text { Planning }\end{array}$ & $\begin{array}{l}\text { Balance of } \\
\text { Payment }\end{array}$ \\
\hline Financial Independence & 1 & $0.749(* *)$ & $0.607(* *)$ \\
Financial Planning & $0.749(* *)$ & 1 & $0.948(* *)$ \\
Balance of Payment & $0.607(* *)$ & $0.948(* *)$ & 1 \\
\hline
\end{tabular}

From the table, there is a strong positive correlation of 0.948 between the two independent variables financial planning and balance of payment. There is also a strong positive correlation of 0.749 between financial independence and financial planning. Between financial independence and balance of payment, there exists a positive correlation of 0.607 showing that both independent variables have a significant effect on dependent variable.

Table 2. Independent and Dependent Variables.

\begin{tabular}{lllllll}
\hline Year/Details & $\mathbf{2 0 0 7 / 2 0 0 8}$ & $\mathbf{2 0 0 8} / \mathbf{2 0 0 9}$ & $\mathbf{2 0 0 9 / 2 0 1 0}$ & $\mathbf{2 0 1 0} / \mathbf{2 0 1 1}$ & $\mathbf{2 0 1 1 / 2 0 1 2}$ & $\mathbf{2 0 1 2} / \mathbf{2 0 1 3}$ \\
\hline Budget Deficit & 102622 & 107826 & 138896 & 152085 & 195372 \\
Balance of Payment & 343427 & 447991 & 464526 & 561765 & 816242 & 828171 \\
Total Debt & 874117 & 1059383 & 1229406 & 1487110 & 1622802 \\
\hline
\end{tabular}

\section{Conclusion}

Financial planning was found to have a direct and positive effect on financial independence of a country. If a country has a deficit in its budget, it has to bridge the gap by borrowing from internal or external lenders and soliciting for grants and donations from other countries and financial institutions. This in essence raised the debt levels and contributed to high dependency levels.

The government spending most of its revenue to finance recurrent expenditure also leads to a shortfall on the funds available to cater for development projects. This in turn forces the government to depend on borrowing, donations and grants to finance its development agenda.

\section{Recommendations}

The researcher concerning the study made a number of recommendations. In relation to the conclusions made, a country should have good financial plans to form a strong foundation in order to avoid dependence. This can be done by reviewing the budget to reduce the deficit and put to manageable levels the amount of funds used to finance the recurrent expenditure part of the budget. This will help increase funds allocated to development and reduce the level of dependence significantly. The government should also improve on revenue collection by sealing all the available loopholes that exist in taxation.

A country should also ensure that the balance of payment is in order. The balance of payment deficit should be reduced to bring down the levels of dependence. This can be done by the country becoming not only an exporter of primary agricultural products but also secondary products. Rapid industrialization can help the country to process the agricultural product it produces and export them at higher prices thus reducing the balance of payment deficit.

Balance of payment was found to have a significant positive relationship with financial independence. If a country has a balance of payment deficit, then it loses on foreign exchange. It has to bridge this gap by sourcing for foreign currency through borrowing. Kenya's balance of payment has always been a deficit since the value of imports has always exceeded the value of imports. This is due to producing primary products for export and then importing the same products as secondary goods at higher prices.

The only tangible data about corruption was by the auditor general estimating that the country lost 270 billion shillings annually due to corruption. According to the researcher, this 
estimate was not sufficient to come up with a conclusion on a direct relationship between corruption and financial independence

\section{References}

[1] Adil, M. (2007). Capital formation, Globalization, Imperialism and monopoly capitalism. International Journal of Business Research, 277-345.

[2] Antiam, A. (2009). Exchange Rates and International Finance. New York: Prentice Hall.

[3] Bourguignon, F. \& Sundberg, M. (2007). Aid Effectiveness Opening the Black Box. American Economic Review, 97(2), 316-321.

[4] CIA. (2013). "Kenya" The World Fact book. Central Intelligence Agency (2012).

[5] Crabbe, O. (1996). International Financial Markets. New York: Prentice Hall.

[6] Craig, B. \& Dollar, D. (2000). Aid, Policy and Growth. The American Economic View.

[7] Fujita, M., Fabrice., H., Joachim, K. \& Guoyong, L. (2009). Assessing the impact of the current financial and economic crisis on global FDI flows. UNCTAD.

[8] Glossary. (2011). U4:Anti-Corruption Resource Centre. CHR.Michelsen Institute.
[9] GOK. (2005). Millennium Development Goals status report. Nairobi: Government of Kenya.

[10] GOK. (2013). Kenya Economic Report 2013. Nairobi: Kenya Institute for Public Policy Research and Analysis.

[11] IMF. (2013). World Economic Outlook. IMF.

[12] Jeffrey, D. (2002). millenium development goals report. UNDP.

[13] John, J. (2008). "Government Debt and Deficits". indianapolis: encyclopedia of economics.

[14] Khapoya, V. (2008). The African Experience. New york: Prentice Hall.

[15] Kwabena, G. (. (2001). Corruption, economic growth and income inequality in Africa. Economics of governance, 183-207.

[16] Lorena, A. \& Raul, A. (2001). Diagnosis corruption. 135-136.

[17] Mathur, B \& Raman, K. (2012). Wide Vision. International Trade and Finance.

[18] Rogelio, A. (2011). IMF Survey Magazine: Countries and Regions. IMF.

[19] Senior, I. (2006). Corruption-The World's Big C. westminster: Institute of Economic Affairs.

[20] Sloman, J. (2004). Economics. Penguin, 555-559.

[21] T.I. (2013). Corruption Perception Index. T.I. 